\title{
The Effect of Compositional Tailoring on the Thermal Expansion and Tribological Properties of PS300: A Solid Lubricant Composite Coating
}

C. DellaCorte

Lewis Research Center

Cleveland, Ohio

and

\section{J.A. Fellenstein}

Ohio Aerospace Institute

Cleveland, Ohio

Prepared for the Annual Meeting sponsored by the Society of Tribologists and Lubrication Engineers Kansas City, Missouri, 1996

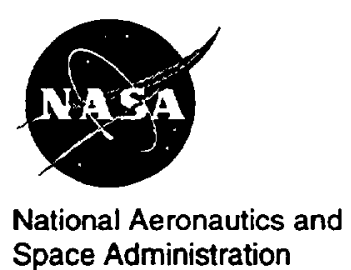


Trade names or manufacturers' names are used in this report for identification only. This usage does not constitute an official endorsement, either expressed or implied, by the National Aeronautics and Space Administration. 


\title{
THE EFFECT OF COMPOSITIONAL TAILORING ON THE THERMAL EXPANSION AND TRIBOLOGICAL PROPERTIES OF PS300: A SOLID LUBRICANT COMPOSITE COATING
}

\author{
C. DellaCorte \\ National Aeronautics and Space Administration \\ Lewis Research Center \\ Cleveland, Ohio 44125 \\ and \\ J.A. Fellenstein \\ Ohio Aerospace Institute \\ Cleveland, Ohio 44142
}

\section{SUMMARY}

This paper describes a research program in which the goal is to alter the thermal expansion coefficient of a composite solid lubricant coating, PS300, by compositional tailoring. PS300 is a plasma sprayed coating consisting of chrome oxide, silver and barium fluoride/calcium fluoride eutectic in $\mathrm{NiCr}$ binder. By adjusting the composition, the thermal expansion coefficient can be altered, and hence chosen, to more closely match a selected substrate preventing coating spallation at extreme temperatures. Thermal expansion coefficients (CTE) for a variety of compositions were measured from 25 to $800{ }^{\circ} \mathrm{C}$ using a commercial dilatometer. The CTE's ranged from 7.0 to $13 \times 10^{-6} /{ }^{\circ} \mathrm{C}$ depending on the binder content. Subsequent tribological testing of a modified composition indicated that friction and wear properties were relatively insensitive to compositional tailoring.

\section{INTRODUCTION}

A new high temperature lubricant composite coating, PS300, has been developed at the author's laboratory (ref. 1). PS300 is a chrome oxide based plasma sprayed coating with silver and barium fluoride/calcium fluoride solid lubricant additions in a $\mathrm{NiCr}$ binder. PS 300 has been demonstrated in a pin-on-disk tribometer under a variety of sliding test conditions from 25 to $650{ }^{\circ} \mathrm{C}$. Published data demonstrates favorable friction and wear properties sliding against metal and ceramic counterfaces suggesting significant application potential for PS300 (refs. 2 and 3).

PS300 represents an improvement over a previously developed chrome carbide based coating, PS200 (ref. 4). One improvement is that by basing the composition on chrome oxide, rather than chrome carbide, costly diamond grinding is not required. This is because chrome oxide is readily machined and polished with $\mathrm{SiC}$ abrasives. Another improvement is that chrome oxide is already fully oxidized minimizing the potential for high temperature oxidative degradation sometimes experienced by PS200 (ref. 5). In addition, at the author's facility, the PS300 composition was found to be easier to plasma spray then PS200 exhibiting less sensitivity to spray parameters and powder variations (ref. 1).

Despite these improvements, one major drawback of the new coating. PS300, has been identified. It is an unexpectedly low coefficient of thermal expansion (CTE). After repeated tests at $650^{\circ} \mathrm{C}$ and above, thermal cycle fatigue and coating spallation were observed for the PS300 deposited onto superalloy substrates.

It was initially assumed that, based upon a simple Rule of Mixtures (ROM) calculation, the CTE for PS300 would be approximately $12.0 \times 10^{-6} /{ }^{\circ} \mathrm{C}$. However, several preliminary experiments involving the plasma spray process suggested a significantly lower CTE. One experiment involved thermally stressing (exposing) coatings with varying thicknesses to assess the maximum temperature above which spalling occurred. It was found that as the coating thickness increased from 0.1 to $1.0 \mathrm{~mm}$, spallation occurred at use temperatures which decreased from 850 to $350^{\circ} \mathrm{C}$. These results suggested that significant residual thermal stresses were present in the coating.

Another preliminary experiment involved preferentially heating or cooling the substrate during the spraying process to intentionally build in residual stresses to reduce or cancel ones caused by, an as yet unquantified, thermal expansion mismatch. This experiment, however, yielded no effect on coating adhesion.

To more conclusively investigate the reason(s) for the coating spallation, free-standing coating samples were made and tested for their expansion characteristics using a commercial dilatometer. Several coating compositions were tested and compared to known calibration standards. 
Tribological pin-on-disk tests were then conducted on a coating composition which displayed favorable/desirable expansion properties for application to superalloy substrates. In these tests, superalloy pins were slid against coated superalloy disks in a high temperature tribometer. Friction and wear properties were compared to the original PS300 coating.

\section{EXPERIMENTAL MATERIALS}

The nominal composition by wt. of $\mathrm{PS} 300$ is $60 \% \mathrm{Cr}_{2} \mathrm{O}_{3}, 20 \% \mathrm{NiCr}$ and $10 \%$ each of $\mathrm{Ag}$ and $\mathrm{BaF}_{2} / \mathrm{CaF}_{2}$ eutectic. Alternate compositions contained increased $\mathrm{NiCr}$ binder content up to $60 \mathrm{wt} \%$ and decreased $\mathrm{Cr}_{2} \mathrm{O}_{3}$ and total lubricant content to 20 and $15 \mathrm{wt} \%$ respectively. Table I gives the exact compositions and coating designations. In addition to the PS300 coatings which utilized a $\mathrm{NiCr}$ binder, specimens were also prepared using two alternate binders made from Co-Ni-Cr and Ni-Al-Mo.

\section{PREPARATION}

The free standing dilatometer samples were made by plasma spraying simple powder blends of each composition into a pre-machined trough fabricated from aluminum. A salt-water treatment of this aluminum trough or mold prevented good adhesion and facilitated specimen removal. The molds were slightly over sized allowing finishing by grinding to achieve rectangular samples $6 \mathrm{~mm} \times 12 \mathrm{~mm} \times 25 \mathrm{~mm}$. The plasma spray parameters used are given in table II and produced samples with nominally the composition of the starting blends. Composition was verified using a calibrated $\mathrm{x}$-ray fluorescence technique. Figure 1 shows a cross section optical micrograph of a PS300 sample.

Thermal expansion standards made from Inconel X-750 and $\mathrm{Al}_{2} \mathrm{O}_{3}$ were ground from wrought and sintered feedstocks, respectively. The expansion coefficients for these calibration standards were provided by the manufacturers. Tribological test specimens were prepared by plasma spray coating of selected compositions onto Inconel -750 disks ( $65 \mathrm{~mm}$ diameter $x 12 \mathrm{~mm}$ thick) to a thickness of $0.5 \mathrm{~mm}$. The coated surfaces were ground to a thickness of $0.3 \mathrm{~mm}$ prior to sliding tests against hemispherically tipped $9.5 \mathrm{~mm}$ diamter $x 25 \mathrm{~mm}$ long Inconel X-750 pins. More details regarding the tribological test procedures can be found in reference 1 .

\section{THERMAL EXPANSION MEASUREMENT}

The thermal expansion coefficients (CTE's) of each sample were measured using a commercially available direct reading, contacting rod dilatometer. With this instrument, the samples rest against one end of an alumina trough and are held in place with a spring loaded rod placed inside a tube furnace and positioned such that the specimen is within the constant temperature zone of the furnace. Thermocouples placed in contact with the specimen are used to measure temperature. Specimen length is monitored by connecting the spring loaded positioning rod to an LVDT (Linear Variable Differential Transformer) with a direct voltage readout. Both specimen temperature and specimen length are read directly by a computer data acquisition system which measures specimen length and temperature every minute.

To conduct a test, the specimen is loaded into the dilatometer instrument and then positioned in the furnace. The furnace is then heated over a two hour period to $800^{\circ} \mathrm{C}$. After a $1 / 2$ hour soak, the LVDT readout is zeroed and the computer data acquisition is begun. The specimen is then allowed to slowly cool by turning off the power to the furnace. Automatic fans provide forced convection cooling to the outside of the furnace and yield a cooling rate of approximately $5{ }^{\circ} \mathrm{C} / \mathrm{min}$. After 2-1/2 hours, the specimens are removed, inspected for dimensional stability, reloaded and re-tested to assess data reproduceability.

The calculation of the representative CTE is made by assuming a constant linear contraction over the test temperature range of interest $\left(200\right.$ to $\left.700^{\circ} \mathrm{C}\right)$. The raw expansion data indicate that over the range of 100 to $700^{\circ} \mathrm{C}$ the CTE's for this composite are constant allowing a simple slope calculation to be used. The CTE values presented are defined as the change in specimen length which occurs between 700 and $200^{\circ} \mathrm{C}$ divided by the length $(25 \mathrm{~mm})$ and the temperature change $\left(500^{\circ} \mathrm{C}\right)$. The $\mathrm{CTE}$ for the calibration standards $\left(\mathrm{Al}_{2} \mathrm{O}_{3}\right.$ and Inconel $\left.\mathrm{x}-750\right)$ are calculated in the same manner. This calculation method, while not generally considered a standard practice, is specifically relevant to the coatings' anticipated use conditions. 


\section{TEST RESULTS AND DISCUSSIONS}

Table III gives the measured CTE's for the test coatings and standards along with the estimated R.O.M. values (or literature values for the standards). From the data, it is evident that the composition does have a significant effect on thermal expansion properties of the PS300 type coatings. The CTE for the base line PS300 composition was measured as $8.2 \times 10^{-6 /}{ }^{\circ} \mathrm{C}$ whereas the CTE for the PS304 was $12.4 \times 10^{-6} /{ }^{\circ} \mathrm{C}$. Furthermore, the simple R.O.M. predictions uniformally over estimated the expansion coefficients. For instance, the predicted CTE value for PS300 is 12.5 suggesting excellent substrate compatibility with superalloys. The measured value, $8.2 \times 10^{-6}$, is significantly lower and helps to explain the observed spalling behavior.

The R.O.M. predictions assume strictly volumetric expansion based upon a homogeneous distribution of perfect spherical phases of the constituents. Clearly, from figure 1, the plasma spray morphology differs from the model. In addition, the prediction ignores the effects of widely varying elastic moduli of the constituents, plastic flow and porosity which may be controlling expansion behavior.

To address these shortcomings in the R.O.M. model, a more elaborate model developed by Levin was employed (ref. 7). This model considers the elastic modulii as well as the volumetric content of each constituent. However, the results were no more accurate than the simple R.O.M. values. This indicates that morphological and other effects may be playing a significant role in the expansion process.

In any case, several of the candidate compositions exhibited CTE's near that of a typical superalloy substrate, Inconel X-750. One of them, PS304 was selected for tribological testing. The results are given in table IV. It can be seen that PS304 gives comparable friction and wear performance to PS300 despite a dramatic change in composition, namely reversing the ratio of $\mathrm{NiCr}$ binder and $\mathrm{Cr}_{2} \mathrm{O}_{3}$ hardening phases. This lack of tribological sensitivity may be due to the retention of approximately the same volume \% of lubricants in PS304 compared to PS300. This suggests that the lubricant additions play an important role in the triboperformance of this composite material system.

The adhesion of the PS304 coating was further assessed by heating an Inconel X-750 coated sample to $900{ }^{\circ} \mathrm{C}$ followed by shock cooling in a water bath. No delamination or spalling was observed. This result confirms that thermal expansion mismatch was the primary coating failure mode for the original PS300 composition.

The data also suggest that the thermal expansion coefficient is largely controlled by the $\mathrm{NiCr}$ binder phase, namely its nickel content. Figure 2 plots CTE vs. nickel wt $\%$ for all of the compositions tested. The data generally fall in a linear pattern which is consistent for other nickel systems described in the literature (ref. 6). Despite changes in the ratios of the other constituents, nickel content appears to determine expansion coefficient. For example, PS304 and PS305 have identical nickel content but significantly different lubricant ( $\mathrm{Ag}$ and fluoride) to hardener $\left(\mathrm{Cr}_{2} \mathrm{O}_{3}\right)$ ratios yet both exhibit essentially equal CTE's.

Binder chemistry appears to play a role also. PS321 and PS322 are based on NiAl-Mo and PS310 and PS311 are based on Co-Cr. The expansion coefficients of PS321 and PS322 fall on the plot of figure 2. This is not surprising, since the binder used in PS321 and PS322 is largely ( $90 \%$ by wt) nickel. The expansion of PS310 and PS311 only fall within the data pattern when expansion is plotted against the \% content of nickel plus cobalt. This, however, is also not surprising since both nickel and cobalt have similar expansion and stiffness properties.

From these results, it appears that to affect expansion, a constituent must exhibit both high strength (stiffness elastic modulus) and an expansion coefficient which significantly differs from the bulk composites. Although the expansion coefficient for both silver and the fluorides are two to four times greater than for PS300, the constituents are too soft (low elasticity modulus) to force the harder phases (nickel and $\mathrm{Cr}_{2} \mathrm{O}_{3}$ ) to expand. Thus a more predictive and appropriate thermal expansion model would take into account expansion coefficients and elastic moduli of each constituent as well as volumetric content and morphology.

\section{CONCLUDING REMARKS}

The thermal expansion coefficient of the PS300 composite coating can be effectively altered through compositional tailoring. The results further indicate that despite significant changes in binder to hardening phase content ratio, the tribological performance is largely unaffected. This may be due to the similar lubricant contents of the compositions tested. Nonetheless, this composite system permits the selection of a coating to match its intended substrate and thus minimize thermal stress induced failures.

There appears to be a linear relation between nickel content and expansion coefficient. Therefore, an empirical relationship between composition and the CTE can be used without making additional CTE measurements. To be 
predictive, a purely theoretical model of expansion properties would need to account for coating morphology, constituent expansion and elastic moduli properties as well as volumetric considerations. Based upon these results, PS300 coating system shows promise for providing lubrication to a wide variety of substrate operating over a large temperature range.

\section{REFERENCES}

1. DellaCorte, C., and Edmonds, B.J., "Preliminary Evaluation of PS300: A New Self-Lubricating High Temperature Composite for Use to $800^{\circ} \mathrm{C}$," NASA TM-107056, November 1995.

2. DellaCorte, C., "The Effect of Counterface on the Tribological Performance of a High Temperature Solid Lubricant Composite from 25 to $650^{\circ} \mathrm{C}$," NASA TM-107183, April 1996.

3. DellaCorte, C., and Laskowski, J.A., "Tribological Evaluation of PS300: A New Chrome Oxide Based Solid Lubricant Coating Sliding Against $\mathrm{Al}_{2} \mathrm{O}_{3}$ from 25 to $650^{\circ} \mathrm{C}$," NASA TM-107163, June 1996.

4. DellaCorte, C., and Sliney, H.E., "Composition Optimization of Self-Lubricating Chromium-Carbide Based Composite Coatings for Use to $760^{\circ} \mathrm{C}$," ASLE Transactions, Vol. 30, 1, pp. 77-83, 1987.

5. Bemis, K., Bogdanski, J.S., DellaCorte, C., and Sliney, H.E., "The Effect of Prolonged Exposure to $750{ }^{\circ} \mathrm{C}$ air on the Tribological Performance of PM212, NASA TM-106472, February 1994.

6. Mankins, W.L., and Lamb, S., "Nickel and Nickel Alloys," in Metals Handbook, 10th Edition, T.B. Zorc editor, ASM International, 1990, Metals Park, Ohio, pp. 428-445.

7. Levin, V.M., On the Coefficients of Thermal Expansion of Heterogeneous Materials, Mech. Of Solids, 2, pp. 58-61, 1967.

TABLE I.-COMPOSITION BY WT\% OF TEST COATINGS

\begin{tabular}{|c|c|c|c|c|}
\hline $\begin{array}{c}\text { Coating } \\
\text { designation }\end{array}$ & $\mathrm{NiCra} / \mathrm{Binder}$ & $\mathrm{Cr}_{2} \mathrm{O}_{3}$ & $\mathrm{Ag}$ & $\mathrm{BaF}_{2} / \mathrm{CaF}_{2} \mathrm{~d}$ \\
\hline PS300 & 20 & 60 & 10 & 10 \\
\hline PS301 & 33 & 50 & 8.3 & 8.3 \\
\hline PS302 & 40.7 & 44.5 & 7.4 & 7.4 \\
\hline PS303 & 47 & 40 & 6.7 & 6.7 \\
\hline PS304 & 60 & 20 & 10 & 10 \\
\hline PS305 & 60 & 25 & 7.5 & 7.5 \\
\hline PS310 & $60 \mathrm{~b}$ & 30 & 10 & 10 \\
\hline PS311 & $50 \mathrm{~b}$ & 20 & 10 & 10 \\
\hline PS320 & $60 \mathrm{c}$ & 30 & 10 & 10 \\
\hline PS321 & $60 \mathrm{c}$ & 20 & 10 & 10 \\
\hline
\end{tabular}

aNiCr contains $80 \mathrm{wt} \% \mathrm{Ni}, 20 \mathrm{wt} \% \mathrm{Cr}$.

bBinder contains $55 \% \mathrm{Co}, 25.5 \% \mathrm{Cr}, 10.5 \% \mathrm{Ni}, 7.5 \%, 0.5 \% \mathrm{C}$.

cBinder contains $90 \% \mathrm{Ni}, 5.5 \% \mathrm{Al}, 5 \% \mathrm{Mo}$.

$\mathrm{dBaF}_{2} / \mathrm{CaF}_{2}$ contains $68 \mathrm{wt} \% \mathrm{BaF}_{2}, 32 \mathrm{wt} \% \mathrm{CaF}_{2}$. 
TABLE II.-NOMINAL PLASMA

SPRAY PARAMETERS USED TO

PRODUCE COATINGS TESTED

\begin{tabular}{|l|c|}
\hline \multicolumn{1}{|c|}{ Parameter } & Value \\
\hline Current & $600 \mathrm{~A}$ \\
\hline Voltage & $30-32 \mathrm{~V}$ \\
\hline Standoff distance & $8-10 \mathrm{~cm}$ \\
\hline $\begin{array}{l}\text { Argon } \\
\text { Arc gas flow rate }\end{array}$ & $35 \mathrm{sl} / \mathrm{min}$ \\
\hline Powder flow rate & $\approx 1 \mathrm{~kg} / \mathrm{hr}$ \\
\hline Powder gas flow rate & $0.4 \mathrm{~m} 3 / \mathrm{hr}$ \\
\hline
\end{tabular}

TABLE III--MEASURED AND R.O.M PREDICTIONS FOR CTE

\begin{tabular}{|c|c|c|}
\hline $\begin{array}{c}\text { Coating } \\
\text { designation }\end{array}$ & $\begin{array}{c}\text { Measured } \\
\mathrm{CTE} \times 10^{-6} /{ }^{\circ} \mathrm{C}\end{array}$ & $\begin{array}{c}\text { Predicted CTE } \\
\times 10-6 /{ }^{\circ} \mathrm{C}\end{array}$ \\
\hline PS300 & $8.2 \pm 0.3$ & 12.4 \\
\hline PS301 & $8.5 \pm 0.2$ & 13.2 \\
\hline PS302 & $9.7 \pm 0.4$ & 12.2 \\
\hline PS303 & $11.0 \pm 1.0$ & 13.5 \\
\hline PS304 & $12.4 \pm 0.5$ & 15.7 \\
\hline PS305 & $12.0 \pm 0.6$ & 14.6 \\
\hline PS310 & $10.7 \pm 0.2$ & 15.1 \\
\hline PS311 & $11.3 \pm 0.3$ & 15.7 \\
\hline PS320 & $12.7 \pm 0.4$ & 15.1 \\
\hline PS321 & $13.0 \pm 0.1$ & 15.7 \\
\hline
\end{tabular}

aUncertainties represent range from repeated tests

TABLE IV.-FRICTION AND WEAR SUMMARY

\begin{tabular}{|c|c|c|c|c|c|}
\hline $\begin{array}{c}\text { Disk } \\
\text { coating }\end{array}$ & $\begin{array}{c}\text { Pin } \\
\text { material }\end{array}$ & $\begin{array}{c}\text { Temperature } \\
{ }^{C} \mathrm{C}\end{array}$ & $\begin{array}{c}\text { Friction } \\
\text { coefficient }\end{array}$ & Kpin, mm3/N-m & Kdisk, mm $3 / \mathrm{N}-\mathrm{m}$ \\
\hline PS300 & INCX750 & 25 & $0.23 \pm 0.05$ & $3.9 \pm 0.5 \times 10-5$ & $6.6 \pm 2.5 \times 10-5$ \\
\hline PS300 & INCX750 & 500 & $0.29 \pm 0.04$ & $1.3 \pm 0.3 \times 10-5$ & $3.9 \pm 0.3 \times 10-4$ \\
\hline PS300 & INCX750 & 650 & $0.31 \pm 0.01$ & $3.1 \pm 0.8 \times 10-5$ & $7.1 \pm 1.6 \times 10^{-4}$ \\
\hline PS304 & INCX750 & 25 & $0.31 \pm 0.05$ & $0.96 \pm 0.3 \times 10-5$ & $4.8 \pm 0.3 \times 10-4$ \\
\hline PS304 & INCX750 & 500 & $0.25 \pm 0.02$ & $0.32 \pm 0.5 \times 10-5$ & $2.8 \pm 0.3 \times 10^{-4}$ \\
\hline PS304 & INCX750 & 650 & $0.23 \pm 0.02$ & $0.38 \pm 0.4 \times 10-5$ & $1.0 \pm 0.1 \times 10^{-4}$ \\
\hline PS304 & INCX750 & 800 & $0.37 \pm 0.03$ & $6.9 \pm 2.0 \times 10-5$ & $2.6 \pm 0.2 \times 10^{-4}$ \\
\hline
\end{tabular}



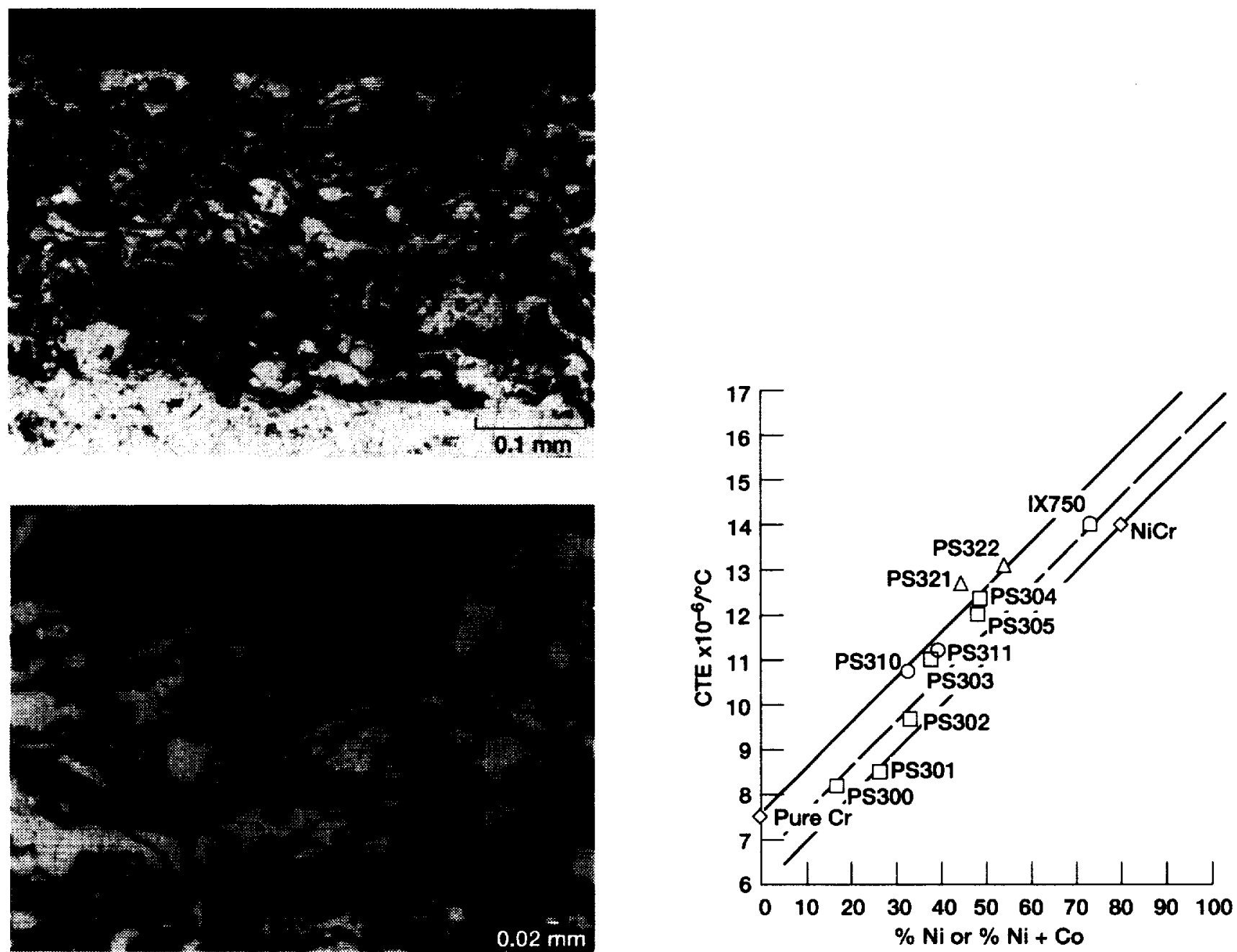

Figure 1.-Cross-sectional optical micrographs of PS300 showing plasma sprayed composite coating structure. Bright areas are $\mathrm{NiCr}$ and $\mathrm{Ag}$; gray areas are $\mathrm{Cr}_{2} \mathrm{O}_{3}$ and black areas are porosity and $\mathrm{BaF}_{2} / \mathrm{CaF}_{2}$.

Figure 2.-Effect of compositon (binder content) on the thermal expansion of PS300 type coatings. 



\begin{tabular}{|c|c|c|c|c|}
\hline \multicolumn{3}{|c|}{ REPORT DOCUMENTATION PAGE } & \multicolumn{2}{|r|}{$\begin{array}{l}\text { Form Approved } \\
\text { OMB No. } 0704-0188\end{array}$} \\
\hline \multicolumn{5}{|c|}{ 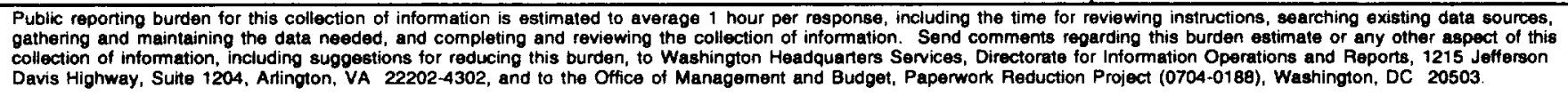 } \\
\hline 1. AGENCY USE ONLY (Leave blank) & \multicolumn{2}{|l|}{$\begin{array}{r}\text { 2. REPORT DATE } \\
\text { October } 1996\end{array}$} & $\begin{array}{l}\text { DATE: } \\
\text { chnica }\end{array}$ & $\begin{array}{l}\text { COVERED } \\
\text { Memorandum }\end{array}$ \\
\hline \multicolumn{3}{|c|}{$\begin{array}{l}\text { 4. TTLE AND SUBTTLE } \\
\text { The Effect of Compositional Tailoring on the Thermal Expansion and } \\
\text { Tribological Properties of PS300: A Solid Lubricant Composite Coating }\end{array}$} & \multicolumn{2}{|c|}{ 5. FUNDING NUMBERS } \\
\hline \multicolumn{3}{|c|}{$\begin{array}{l}\text { 6. AUTHOR(S) } \\
\text { C. DellaCorte and J.A. Fellenstein }\end{array}$} & \multicolumn{2}{|c|}{ WU-505-63-1A } \\
\hline \multicolumn{3}{|c|}{$\begin{array}{l}\text { National Aeronautics and Space Administ } \\
\text { Lewis Research Center } \\
\text { Cleveland, Ohio } 44135-3191\end{array}$} & \multicolumn{2}{|c|}{ E-10423 } \\
\hline \multicolumn{3}{|c|}{ 9. SPONSORINGMONTORING AGENCY NAME(S) AND ADDRESS(ES) } & \multicolumn{2}{|c|}{ NASA TM-107332 } \\
\hline \multicolumn{5}{|c|}{$\begin{array}{l}\text { 11. SUPPLEMENTARY NOTES } \\
\text { Prepared for the Annual Meeting sponsored by the Society of Tribologists and Lubrication Engineers, Kansas City, Missouri, } \\
\text { May } 18-22,1997 \text {. C. DellaCorte, NASA Lewis Research Center and J.A. Fellenstein, Ohio Aerospace Institute, } 22800 \text { Cedar } \\
\text { Point Road Cleveland, Ohio } 44142 \text {. Responsible person C. DellaCorte, organization code 5140, (216) 433-6056. }\end{array}$} \\
\hline \multicolumn{3}{|c|}{$\begin{array}{l}\text { 12a. DISTRIBUTION/AVAILABILTYY STATEMENT } \\
\text { Unclassified - Unlimited } \\
\text { Subject Category } 24 \\
\text { This publication is available from the NASA Center for AeroSpace Information, (301) 621-0390. }\end{array}$} & \multicolumn{2}{|c|}{ 12b. DISTRIBUTION CODE } \\
\hline \multicolumn{5}{|c|}{$\begin{array}{l}\text { This paper describes a research program in which the goal is to alter the thermal expansion coefficient of a composite } \\
\text { solid lubricant coating, PS300, by compositional tailoring. PS } 300 \text { is a plasma sprayed coating consisting of chrome } \\
\text { oxide, silver and barium fluoride/calcium fluoride eutectic in NiCr binder. By adjusting the composition, the thermal } \\
\text { expansion coefficient can be altered, and hence chosen, to more closely match a selected substrate preventing coating } \\
\text { spallation at extreme temperatures. Thermal expansion coefficients (CTE) for a variety of compositions were measured } \\
\text { from } 25 \text { to } 800^{\circ} \mathrm{C} \text { using a commercial dilatometer. The CTE's ranged from } 7.0 \text { to } 13 \times 10^{-6} /{ }^{\circ} \mathrm{C} \text { depending on the binder } \\
\text { content. Subsequent tribological testing of a modified composition indicated that friction and wear properties were } \\
\text { relatively insensitive to compositional tailoring. }\end{array}$} \\
\hline \multirow{2}{*}{\multicolumn{3}{|c|}{$\begin{array}{l}\text { 14. SUBJECT TERMS } \\
\text { Thermal expansion; Composite; Solid lubricant; Friction; Wear; Coating }\end{array}$}} & & $\begin{array}{c}\text { 15. NUMBER OF PAGES } \\
09\end{array}$ \\
\hline & & & & $\begin{array}{r}\text { 16. PRICE CODE } \\
\text { A02 }\end{array}$ \\
\hline $\begin{array}{l}\text { 17. SECURTY CLASSIFICATION } \\
\text { OF REPORT } \\
\text { Unclassified }\end{array}$ & $\begin{array}{l}\text { 18. SECURTYY CLASSIFICATION } \\
\text { OF THIS PAGE } \\
\text { Unclassified }\end{array}$ & $\begin{array}{l}\text { 19. SECURITY CLASSIFICAT } \\
\text { OF ABSTAACT } \\
\text { Unclassified }\end{array}$ & TION & 20. LIMITATION OF ABSTRACT \\
\hline
\end{tabular}

